treatment for 10 minutes at $370^{\circ} \mathrm{C}$, exhibits identical colour co-ordinates, namely $L^{\star}=86, a^{\star}=3$ and $\mathrm{b}^{\star}=12$, in both conditions.

\section{Conclusions}

The use of a computerized spectrophotometer to measure alloy colour is a major advance in quantifying this important design criterion. The emphasis on gold-silver-copper alloys for initial work corresponds to the predominance of jewellery and dental alloys based on this system. A quantitative colour map, based on a uniform colour space, is now available, which reveals that composition, the controlling factor, and alloy colour are related in a complex manner. The concepts exposed above have been used in studies of alloys with more than three constituents and, in particular, have been applied successfully in the formulation of new dental gold alloys meeting specific criteria. With the current interest in dental alloys with lowered noble metal contents, application of these same experimental methods to quantifying colour stability (tarnish resistance) is proving a valuable tool for alloy development.

\section{References}

1 E. F. I.Roberts and K. M.Clarke, Gold Bull., 1979, 12,(1), 9-19

2 D. C. Wright and R. M. German, in 'Proc. Dent. Mater. Group, Int. Assoc. Dent. Res.', New Orleans, LA., March 1979, available from Dr. D. Eick, School of Dentistry, Oral Roberts University, Tulsa, OK., U.S.A.

3 M. M. Guzowski, D. C. Wright and R. M. German, presentation to the Third International Precious Metals Conference, Chicago, IL., U.S.A., May 1979

4 P. S. Hunter, Ind. Res. Dev., 1979 (August), 67-72

5 J. Leuser, Metall, 1949, 3, ]05-110,128

Leuser's diagram was reproduced in:

'Gold: Recovery, Properties and Applications', edited by E. M. Wise, D. Van Nostrand Co., Inc., Princeton, NJ., 1964 p. 262

W. S. Rapson and T. Groenewald, 'Gold Usage', Academic Press, London, 1978, p. 37

A. S. McDonald and G. Sistare, Gold Bull., 1978, 11, (2), 68

\title{
Cloth of Gold and its History
}

\section{The Gold and Silver Wyre-Drawers}

BY ELIZABeth GLover, Phillimore, Chichester, England, 1979, 91 pages, $£ 17.50$

There are many records of the extravagant display of finery that characterized the Field of the Cloth of Gold, the name given to the month-long meeting of Henry VIII and Francis I, the French king, near Calais in 1520, and most visitors to Britain must at some time have had an opportunity to admire the gorgeous uniforms of the State Trumpeters of the Household Cavalry, the Royal Heralds or the Drum Majors of the Brigade of Guards. Much of this splendour comes of course from the embroidery worked in gold wire. If rather less resplendent, the uniforms of the higher echelons of the world's armies, navies and air forces all display at least something of the same regard for gold braid, while ecclesiasical vestments have for many centuries been richly decorated by the same means.

The manufacture of gold wire - or more strictly goldclad silver wire - for use in textiles and embroidery is an ancient craft; it is mentioned, for example, in the Book of Exodus, where the making of the ephod for the tabernacle is described:

'The gold was beaten into thin plates, cut and twisted into braid to be worked in by a seamstress with the violet, purple and scarlet yarn, and fine linen.'

In fact, the very early technique did consist of covering skins or vellum with gold foil, cutting into very thin strips and winding this closely round a thread of silk or hemp. By the fifteenth century, however; wire drawing had been practised for some time, while flattening of the wire to enable it to be wound round silk to make thread was introduced in the mid-sixteenth century. Well before this time English embroidery with a plentiful use of gold and silver wire was highly regarded throughout Europe and in fact became known as Opus Anglicanum. This was essentially a Londonbased cottage industry and the present volume gives a most fascinating history of it and of the craft guild that was formed to control the trade, to maintain standards and to establish a seven-year period of apprenticeship.

The author is a skilled and experienced archivist, and she has had full access to the records and minute books of the Worshipful Company of Gold and Silver Wyre-Drawers, one of the smaller City Livery Companies of London and one that still maintains connections with the trade. Its first full charter was granted in 1693, although a rather unsatisfactory charter of sorts had been obtained from Charles I in 1623. One John Garill, a well known gold and silver wire-drawer, had claimed in 1662 to have developed a new process 'for casting and preparing gold and silver ingots for making wire and lace' and was granted a patent for his invention in the following year. This of course aroused the anger of his competitors, some thirty or so master craftsmen who controlled large numbers of out-workers, and after lengthy and expensive negotiations a proper charter was granted.

The book gives details of all the known gold and silver wire-drawers in London in the early period and goes on to describe the trade and its markets in later centuries. The Industrial Revolution brought about great changes in the nineteenth century, and part of the London trade was lost to Lancashire, where the weaving of gold thread into cotton textiles had the obvious advantage that it withstood the bleaching process, and where powered machinery was adopted. New outlets were found and trade expanded throughout the world, but today, unfortunately, only one firm remains - in Preston in Lancashire. However, as Mrs. Glover concludes 'it is enough to say that the industry survives and that what it does is well done'.

This account of a minor but highly decorative use of gold - including a technical chapter on modern production practice - gives a fascinating picture of progress in an ancient craft over more than five hundred years. 